\title{
Characterization of cellulolytic activities of Bjerkandera adusta and Pycnoporus sanguineus on solid wheat straw medium
}

\author{
Rosa E. Quiroz-Castañeda \\ Centro de Investigación en Biotecnología \\ Universidad Autónoma del Estado de Morelos \\ Cuernavaca, Morelos, México \\ Edgar Balcázar-López \\ Centro de Investigación en Biotecnología \\ Universidad Autónoma del Estado de Morelos \\ Cuernavaca, Morelos, México \\ Edgar Dantán-González \\ Centro de Investigación en Biotecnología \\ Universidad Autónoma del Estado de Morelos \\ Cuernavaca, Morelos, México \\ Alfredo Martinez \\ Instituto de Biotecnología \\ Universidad Autónoma Nacional De México \\ Cuernavaca, Morelos, México \\ Jorge Folch-Mallol \\ Centro de Investigación en Biotecnología \\ Universidad Autónoma del Estado de Morelos \\ Cuernavaca, Morelos, México \\ Claudia Martínez Anaya* \\ Instituto de Biotecnología \\ Universidad Nacional Autónoma de México \\ Av. Universidad 2001, Col. Chamilpa 62210 \\ Cuernavaca, Morelos, México \\ E-mail: cma@ibt.unam.mx
}

Financial support: CONACYT grant 48256Z and Conacyt scholarships to Rosa E. Quiroz-Castañeda (No. 47895) and Edgar Balcázar-López (No. 204223); and a postdoctoral fellowship to Claudia Martínez-Anaya (Exp. No.050272).

Keywords: B. adusta, cellulases, P. sanguineus, wheat straw, xylanases.

Abbreviations: CMC: carboxymethylcellulose

DNS: dinitrosalycilic acid

PA: polyacrylamide

Cellulolytic properties of two white rot fungi, Bjerkandera adusta and Pycnoporus sanguineus, cultivated on wheat straw agar medium, were characterized and compared. Optimal growing parameters for maximum enzyme production for both fungi were wheat straw medium $\mathrm{pH} 5$ and $28^{\circ} \mathrm{C}$. $B$. adusta showed, on the 6th day of culture, carboxymethylcellulose (CMC)ase activity levels 1.6 times higher than maximal $P$. sanguineus activity, achieved on the 8th day. $B$. adusta supernatants also displayed higher activity levels towards xylan (3.6-fold) compared to those of $P$. sanguineus. However, enzymes from $P$. sanguineus were more robust resisting one hour incubation at high temperatures (up to $80^{\circ} \mathrm{C}$ ), and exhibiting activity and stability in pH range from 2 to 8 . Cellulolytic activities, with molecular masses ranging from 25 to $90 \mathrm{kDa}$, from the two species were detected in zymograms.

White rot fungi have the capacity to exploit all wood components due to the secretion of a variety of lignocellulolytic enzymes (Perez et al. 2002; Martínez et al. 2005). Much attention has been focused on finding such hydrolytic activities given their potential use in different industries such paper biopulping, human and animal feeding, and the production of cellulosic bioethanol

*Corresponding author 
a

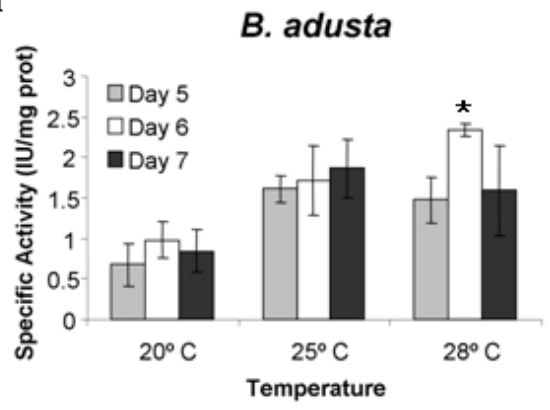

b

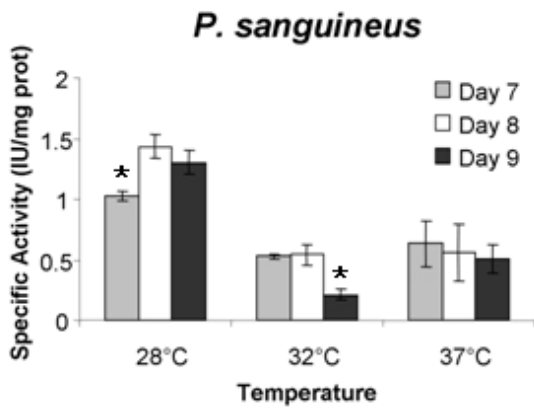

Figure 1. Influence of different growing temperatures at different times of culture on CMCase production by $B$. adusta (a) and $P$. sanguineus (b). Asterisks indicate statistically significant differences $(P<0.05$, ANOVA) within each group of days analyzed.

(Alborés et al. 2006; Lee et al. 2007; Doi, 2008). Bioethanol is produced mainly by fermenting sucrose or glucose from sugarcane, sugar beets and corn. Given that not all countries overproduce these feedstocks, other carbohydrate sources are being explored (Kim and Dale, 2004; Bayer et al. 2007). Vegetal biomass is composed of three main polymers, lignin, cellulose and hemicelluloses. Cellulose is organized as glucose polymeric long lineal chains, arranged in different levels of fibrils that are associated by intramolecular interactions. Hemicelluloses, in contrast, are ramified polymers composed of different types of carbohydrates and phenolic compounds, among which xylan, glucan and arabinoglucan form the sugar backbone of the structure. Because sugar production from biomass is a key limiting step in industrial processes, harsh physical-chemical pretreatments (such as steam explosion, with or without diluted sulfuric acid) are used to loosen lignin and release fibrils of cellulose and monomers of hemicellulose components (Wyman et al. 2005). Pretreatment also decreases the recalcitrance of crystalline cellulose by generating pores on its structure making it more accessible to hydrolytic enzymes (Nguyen et al. 2000; Nagle et al. 2002; Söderström et al. 2002). The holocellulose (cellulose and hemicellulose) can be then completely saccharified by a number of enzymes due to the synergism displayed by combinations of endo- and exoglucanases and $\beta$-glucosidases (Nidetzky et al. 1994). Industrially-produced biomass sugars require large-scale cellulose degradation for fuel production. Traditionally, commercial cellulases preparations from Trichoderma have been used, and most studies regarding fungal cellulose degradation have been carried out in this genre and other ascomycetes (Gerhardt et al. 2007; Villena and GutiérrezCorrea, 2007). However, contrary to ascomycetes, basidiomycetes are organisms specialized in wood degradation, and it is surprising that little work has been done regarding the characterization of basidiomycetes cellulolytic capacities. It is for this reason, important to establish the whole cellulolytic capabilities of wooddegrading fungi. Given that harsh pretreatments are used to obtain sugars from lignocellulose, it is important to screen for robust cellulolytic activities that can be efficient at high temperatures or extreme $\mathrm{pH}$ values that match industrial conditions.

In this work we analyzed the cellulolytic properties of two white rot fungi, Bjerkandera adusta and Pycnoporus sanguineus, originally isolated from two different geographical locations. B. adusta strain UAMH 8258, a basidiomycete well known for its elevated ligninase activity (Wang et al. 2003), and unable to grow at $37^{\circ} \mathrm{C}$, was isolated from temperate woods of the northern hemisphere. $P$. sanguineus CEIBMD01, a fungal strain able to grow at moderately high temperatures given its tropical origin (Dantán-González et al. 2008) was isolated from an oilpolluted environment in the south of the state of Veracruz (México).

In this work, culture conditions and levels of cellulolytic enzymes production by $B$. adusta and $P$. sanguineus grown in wheat straw medium were compared. Zymogram analyses permitted the detection of a number of bands with cellulolytic and hemicellulolytic activities expressed by both fungi.

\section{MATERIALS AND METHODS}

\section{Strains}

Bjerkandera adusta UAMH 8258 was kindly provided by Dr. R. Vazquez-Duhalt (Wang et al. 2003). Pycnoporus sanguineus CEIBMD01 was growing on a dead tree bark covered with petroleum spill when collected (DantánGonzález et al. 2008).

\section{Culture conditions}

To ensure that the fungi only used wheat straw as the sole carbon source, they were firstly grown at $28^{\circ} \mathrm{C}$ in precultures of GMY medium (1\% glucose, $0.35 \%$ malt extract, $0.25 \%$ yeast extract, $0.2 \% \quad \mathrm{KH}_{2} \mathrm{PO}_{4}$ and $0.05 \%$ $\mathrm{MgSO}_{4} \times 7 \mathrm{H}_{2} \mathrm{O}, 1.5 \%$ agar, $\mathrm{pH} 4.5$ adjusted with phosphoric acid) until mycelia had filled the Petri dish. A passage was 
a

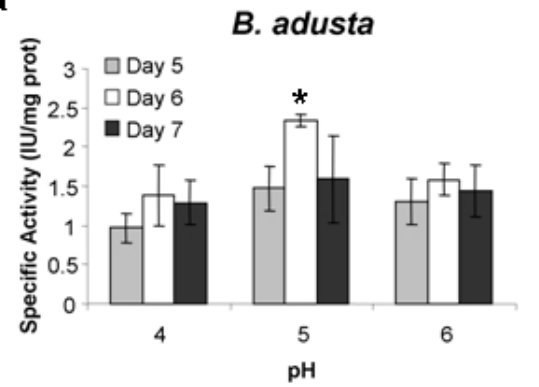

b

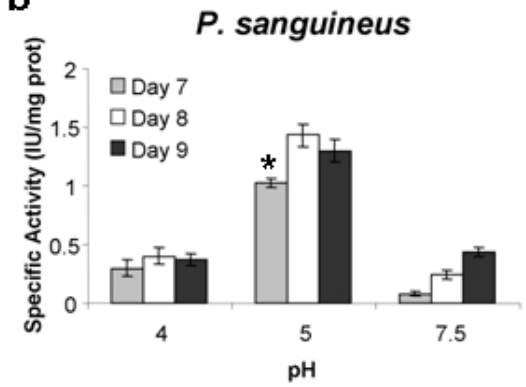

Figure 2. Influence of $\mathrm{pH}$ of the culture media at different times of culture on CMCase production by $B$. adusta (a) and $P$. sanguineus (b). Asterisks indicate statistically significant differences $(P<0.05$, ANOVA) within each group of days analyzed.

then performed with $0.25 \mathrm{~cm}^{2}$ inoculums placed in the center of another Petri dish containing a modified (Inglis et al. 2000) mineral base medium $\left(7.8 \mathrm{mg} / \mathrm{L} \mathrm{CuSO}_{4} \times 5 \mathrm{H}_{2} \mathrm{O}\right.$, $18 \mathrm{mg} / \mathrm{L} \mathrm{FeSO}_{4} \times 7 \mathrm{H}_{2} \mathrm{O}, 500 \mathrm{mg} / \mathrm{L}^{\mathrm{MgSO}} 4 \times 7 \mathrm{H}_{2} \mathrm{O}, 10$ $\mathrm{mg} / \mathrm{L} \mathrm{ZnSO}$, $50 \mathrm{mg} / \mathrm{L} \mathrm{KCl,} 1 \mathrm{~g} / \mathrm{L} \mathrm{K}_{2} \mathrm{HPO}_{4}$ and $2 \mathrm{~g} / \mathrm{L}$ $\mathrm{NH}_{4} \mathrm{NO}_{3}, 1.5 \%$ agar; $\mathrm{pH}$ was adjusted to 5 , or 4 and 6 when required- with phosphoric acid) depleting and depriving the samples of a carbon source (mycelia in this medium were very faint and failed to develop after 5 days). Finally, for the experimental cultures, $0.25 \mathrm{~cm}^{2}$ squares taken from the mineral base medium were placed in the center of a plate containing mineral base medium plus $2 \%$ powdered wheat straw as the sole carbon source. In this medium mycelia grew healthily to confluence. Wheat straw (Triticum aestivum) was pulverized in a coffee grinder (Braun) until a homogeneous powder was observed (with maximum and minimum particle sizes of 3 and $0.5 \mathrm{~mm}$, respectively). Temperatures and periods of incubation varied according to each experiment (from 20 to $37^{\circ} \mathrm{C}$ and from 1 to 12 days, respectively; see results).

\section{Enzymatic assays and protein determination}

Enzymatic activity and protein concentration were assayed from the supernatants obtained from the solid cultures as follows: agar media was cut into pieces for collection from the Petri dishes and placed in $50 \mathrm{ml}$ centrifuge tubes, then centrifuged at 2,504 $\mathrm{x} \mathrm{g}$ at $4^{\circ} \mathrm{C}$ for $30 \mathrm{~min}$; the volume recovered varied between 3 and $4 \mathrm{ml}$. Supernatants were clarified by filtration through $0.45 \mu \mathrm{m}$ nitrocellulose filters (Pall). For enzymatic activity measurements the following substrates were used: $2 \%$ carboxymethylcellulose (CMC, Sigma), 2\% microcrystalline cellulose (Avicel ${ }^{\circledR}$ PH-101, Fluka), $0.25 \%$ cellobiose (Sigma), and $2 \%$ oat spelt and birchwood xylans (Sigma), dissolved in $50 \mathrm{mM}$ citrate buffer $\mathrm{pH}$ 5. Enzymatic reactions contained $200 \mu \mathrm{l}$ of supernatant, $300 \mu \mathrm{l}$ of $50 \mathrm{mM}$ citrate buffer $\mathrm{pH}$ 5, plus 500 $\mu \mathrm{l}$ of each substrate solution. The reaction mixtures were incubated at $50^{\circ} \mathrm{C}$ for $30 \mathrm{~min}$. Reducing sugars were determined using the 3,5-dinitrosalycilic acid (DNS) assay according to Miller (1959). Briefly, $50 \mu \mathrm{l}$ aliquots were taken every 5 min (after adding the supernatant to the reaction mixture) up to $45 \mathrm{~min}$, then mixed with $50 \mu \mathrm{l}$ of a
DNS solution, boiled for 5 min and immediately cooled on ice for $5 \mathrm{~min}$. Finally $500 \mu \mathrm{l}$ of water were added and absorbance measured at $540 \mathrm{~nm}$ in a spectrophotometer (BioMate, ThermoSpectronic). Absorbance readings were compared to glucose or xylose standard curves ranging from 0.1 to $2 \mathrm{mg} / \mathrm{ml}$; values were graphed against time, and the slope was calculated to determine the velocity of the reaction. Released reducing sugars vs. time were used to calculate enzymatic activities, considering 1 IU equivalent to $1 \mu \mathrm{mol}$ of glucose or xylose released per min under the assayed conditions. For specific activity calculation, protein concentrations in $\mathrm{mg} / \mathrm{ml}$ were determined by the Folin (Hycel de Mexico)-Lowry method (Lowry et al. 1951) with a bovine serum albumin (BSA) standar curve.

\section{Optimal temperature and $\mathrm{pH}$ of CMCase activity}

Enzymatic reactions were carried out as explained above at incubation temperatures between 30 and $90^{\circ} \mathrm{C}$. For optimal $\mathrm{pH}$ screening, a range from 3 up to 8 was tested with 50 $\mathrm{mM}$ sodium citrate buffer.

\section{Thermal- and pH-stability of the cellulolytic enzymes}

To test the heat stability of the cellulases in the crude supernatants, $200 \mu \mathrm{l}$ of supernatant were incubated for $1 \mathrm{hr}$ at different temperatures ranging from 30 to $90^{\circ} \mathrm{C}$. Treatments were stopped on ice and the remaining activity was measured at $50^{\circ} \mathrm{C}$ and $\mathrm{pH}$ 5. For pH stability, $200 \mu \mathrm{l}$ of supernatant were incubated in one volume of buffer solutions at $\mathrm{pH}$ values ranging from $\mathrm{pH} 2$ up to 10 for $1 \mathrm{hr}$ at room temperature. System buffers were Mcllvaine $(\mathrm{pH} 2$

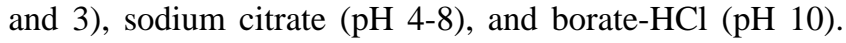
The remaining activity was measured at $50^{\circ} \mathrm{C}$ and $\mathrm{pH} 5$.

\section{Statistical calculations}

The general linear model (GLM) data analysis for this paper was generated using statistical analysis system (SAS) software 9.1 for Windows XP (SAS Institute Inc; Cary, NC, USA). 
a

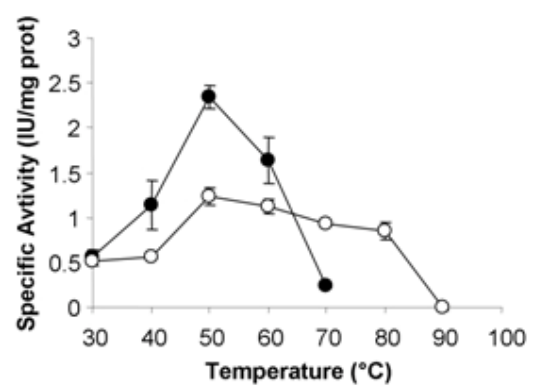

b

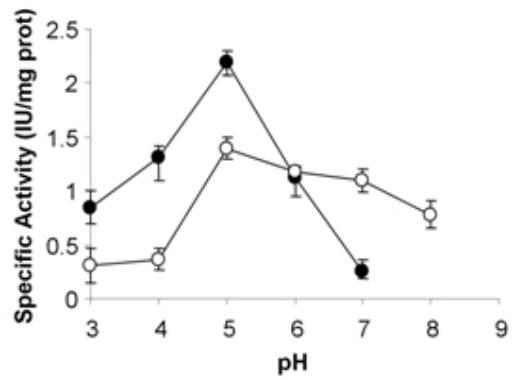

Figure 3. CMCase activity in culture supernatants at different reaction temperatures (a), and pH (b). Black circles, B. adusta; white circles, $P$. sanguineus.

\section{Zymograms}

Proteins in supernatants were precipitated at two different acetone concentrations: $20 \%$ and $80 \%$. Pellets were dissolved in $100 \mu \mathrm{l}(20 \%)$ and $2 \mathrm{ml}(80 \%)$ of $50 \mathrm{mM}$ citrate buffer. Protein concentration was quantified by the FolinLowry method, and $25 \mu \mathrm{g}$ were run in 10\% PAGE. For identification of CMCase activities, after electrophoresis, gels were treated as previously described (Mateos et al. 1992). Briefly, gels were washed three times (40 min each) in PCA buffer ( $50 \mathrm{mM} \mathrm{KH}_{2} \mathrm{PO}_{4}, 50 \mathrm{mM}$ citric acid $\mathrm{pH}$ 5.2). The polyacrylamide gel was laid on top of a $0.5 \%$ agarose gel containing $0.2 \% \mathrm{CMC}$, and incubated for $6 \mathrm{hrs}$ at $30^{\circ} \mathrm{C}$ in a humid chamber. Agarose gels were next stained with $0.1 \%$ Congo red for $30 \mathrm{~min}$ followed by one wash with $1 \mathrm{M}$ $\mathrm{NaCl}$. For xylanase activity detection, 10\% SDSpolyacrylamide gels containing $0.2 \%$ birchwood xylan were run. Then the polyacrylamide (PA) gels were washed twice (30 min each) with $50 \mathrm{mM}$ sodium acetate buffer $\mathrm{pH}$ 5.5 containing $25 \%$ isopropanol, and one wash without isopropanol (Lee et al. 1993), and then incubated for $5 \mathrm{~min}$ at $60^{\circ} \mathrm{C}$. Congo red staining of the PA gels was followed as mentioned above for agarose gels. Both, agarose and PA gels were submerged in 5\% acetic acid for $10 \mathrm{~min}$ to convert the color of Congo red to purple, thus improving visibility of the bands. The molecular weight of the bands was estimated using a SDS-PAGE marker (Invitrogen).

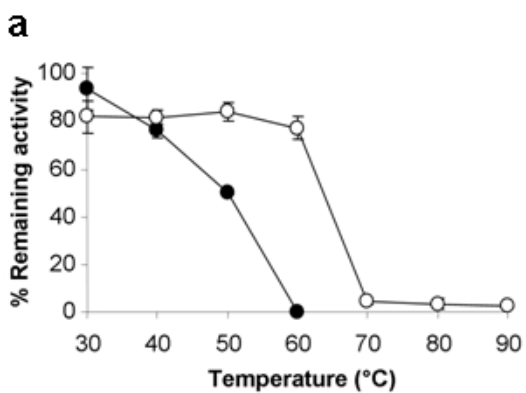

\section{RESULTS}

\section{Culture conditions for maximum CMCase activity production}

Basidiomycetes fungi are excellent lignocellulolytic organisms. We were interested in establishing the optimal culture conditions for CMCase production of two species (Bjerkandera adusta and Pycnoporus sanguineus) isolated from very different geographical origins (cool forest the former and tropical the latter). Surprisingly, it was found that when the temperature of the growing cultures was varied, $28^{\circ} \mathrm{C}$ was the optimum for CMCase activity production in both strains (Figure 1), even though $P$. sanguineus is able to grow better at more elevated temperatures $\left(37^{\circ} \mathrm{C}\right)$ (Dantán-González et al. 2008). B. adusta presented considerable levels of cellulase activity at $25^{\circ} \mathrm{C}$ during the three days analyzed, reaching up to around $2 \mathrm{IU} / \mathrm{mg}$ (Figure 1a); on the oher hand, when $P$. sanguineus was grown at $32^{\circ}$ or $37^{\circ} \mathrm{C}$ the specific activity sharply decreased to less than half of that observed at $28^{\circ} \mathrm{C}$ (Figure 1b). With respect to the $\mathrm{pH}$ influence of the culture medium, the highest cellulolytic activity from $B$. adusta was detected at $\mathrm{pH} 5$ with no significant differences observed when grown at pH 4 and 6 (Figure 2a). Similarly, $P$. sanguineus preferred $\mathrm{pH} 5$ for maximum CMCase activity levels, higher values of $\mathrm{pH}$ reduced the activity dramatically to less than one third, while at $\mathrm{pH} 6$ the

\section{b}

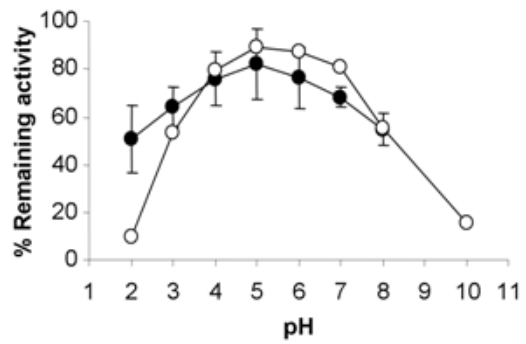

Figure 4. Stability of CMCase activity after incubation at different temperatures (a), and pH (b). Black circles, B. adusta; white circles, $P$. sanguineus. 
activity was one half of that showed at $\mathrm{pH} 5$ (Figure 2b). One difference between the species was the time at which CMCase activity was maximum. At $28^{\circ} \mathrm{C}$ and $\mathrm{pH} 5 \mathrm{~B}$. adusta exhibited its maximum CMCase activity on the 6th day, reaching $2.4 \mathrm{IU} / \mathrm{mg}$, whereas the activity from $P$. sanguineus was highest on the 8th day showing $1.4 \mathrm{IU} / \mathrm{mg}$ (data not shown).

\section{Cellulolytic activity characterization in culture supernatants}

\section{Enzymatic reaction conditions}

Different properties of the enzymes contained in the supernatants from cultures of both species were analyzed. CMCase activity versus temperature of reaction profiles were obtained for each fungus. Despite both fungi showed maximal cellulolytic activities at $50^{\circ} \mathrm{C}, B$. adusta presented a peak with a significant decline both towards higher or lower temperatures. On the other hand, the enzymatic activity of the $P$. sanguineus supernatant maintained 40 to $85 \%$ of activity in the ranges of $30^{\circ} \mathrm{C}$ to $40^{\circ} \mathrm{C}$ and $60^{\circ} \mathrm{C}$ to $80^{\circ} \mathrm{C}$ (Figure 3a). Likewise, when the reaction was carried out at different $\mathrm{pH}$, enzymes from both species were more active at $\mathrm{pH} 5$ (Figure 3b); however, once again, those from B. adusta presented almost half the activity shown at $\mathrm{pH} 5$ for $\mathrm{pH}$ below 4 and above 6 . In contrast, the cellulolytic activity from $P$. sanguineus were elevated at more alkaline $\mathrm{pH}$, showing more than $50 \%$ of the maximum activity at $\mathrm{pH}$ 8 (Figure 3b).

\section{Enzymatic tolerance}

Robustness of the cellulolytic enzymes is a key factor for industrial applications. The thermotolerance of the cellulases from the two fungi was analyzed. B. adusta supernatants showed $94 \%$ of remaining activity $(2.2 \mathrm{IU} / \mathrm{mg}$, compared to $2.4 \mathrm{IU} / \mathrm{mg}$ achieved at optimum conditions of $\mathrm{pH}$ and temperature) when incubated below $50^{\circ} \mathrm{C}$. However, this activity was rapidly lost when the temperature of incubation was increased (Figure 4a). At $40^{\circ} \mathrm{C}$ only $76 \%$ of the original activity was retained, and at $50^{\circ} \mathrm{C}$ half of the activity was lost. The enzymes that confer CMCase activity could not tolerate temperatures of $60^{\circ} \mathrm{C}$ and above. In contrast, those from $P$. sanguineus resisted up to $60^{\circ} \mathrm{C}$ showing approximately $80 \%$ of the original activity after $1 \mathrm{hr}$ of incubation (Figure 4a). In this case CMCase activity was lost in $1 \mathrm{hr}$ at temperatures above $70^{\circ} \mathrm{C}$. In addition, the effect of incubating the supernatants during 1 $\mathrm{hr}$ in buffers with $\mathrm{pH}$ ranging from very acidic to very alkaline was analyzed. In this case, while $B$. adusta enzymes retained above $50 \%$ of the CMCase activity at $\mathrm{pH}$ 2 and 8 (Figure 4b) $P$. sanguineus enzymes were almost inactive at $\mathrm{pH} 2$, but retained $80 \%$ of activity at $\mathrm{pH} 7$, and showed more than $50 \%$ residual activity at $\mathrm{pH} 3$ and 8 . However, activity at $\mathrm{pH} 10$ was reduced by $84 \%$ (Figure $4 b)$.

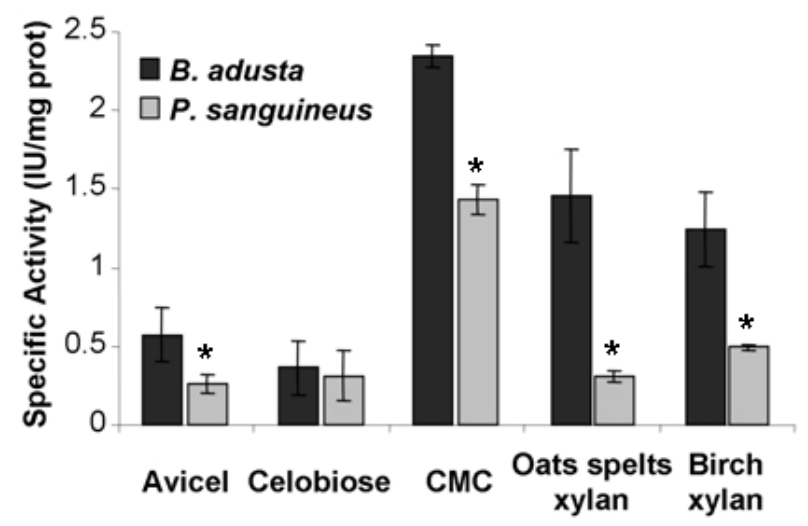

Figure 5. Cellulolytic activities towards different cellulosic substrates in supernatants of $B$. adusta (gray bars), and $P$. sanguineus (black bars) from 6- and 8-day cultures, respectively, after growth in wheat straw media at $28^{\circ} \mathrm{C}$ and pH 5. Asterisk indicates statistically significant differences $(P<$ 0.05 , ANOVA) between the fungi.

\section{Substrate specificities}

To evaluate the enzymes specificities, different substrates were tested in the enzymatic reactions. Exo-glucanase activity was evident in both species by the use of microcrystalline cellulose (Avicel), with $B$. adusta showing higher enzymatic activity $(0.6 \mathrm{IU} / \mathrm{mg})$ than $P$. sanguineus (0.3 IU/mg; Figure 5). Cellobiose was hydrolyzed by $\beta$ glucosidases practically to the same extent by the two fungi (Figure 5). CMC is formed by amorphous cellulose, a substrate for endo-glucanases. Liberated cellooligosaccharides from CMC by endo-glucanases then become substrate for $\beta$-glucosidases increasing the concentration of reducing sugars. Therefore, it was not surprise to find the most elevated values for both fungi when CMC was used as the reaction substrate (2.4 $[B$. adusta] and $1.43 \mathrm{IU} / \mathrm{mg}$ [P. sanguineus]; Figure 5). Xylanase activity towards xylan of two different sources (oat spelt and birchwood) was produced by the two fungi. $B$. adusta xylanases were more active than those from $P$. sanguineus by 5 and 2.5 times for both substrates respectively.

\section{Zymograms}

Protein bands with cellulolytic and xylanolytic activities were identified using gel electrophoresis and Congo red staining. Five possible cellulase bands were observed from acetone-precipitated supernatants of B. adusta (Figure 6a). The band of largest molecular weight was approximately of $90 \mathrm{kDa}$, whereas the other four bands were around 25, 35, 40 and $50 \mathrm{kDa}$ (Figure 6a). On the contrary, P.sanguineus showed only two prominent CMCase activity bands of approximately 25 and $50 \mathrm{kDa}$ when precipitated with $80 \%$ acetone (Figure 6a). The $50 \mathrm{kDa}$ band was the only CMCase activity present following precipitation at $20 \%$ acetone (Figure 6a), which could be a useful characteristic for downstream processing. In the case of xylanases, $B$. 
adusta produced a unique activity band which precipitated free of other contaminant proteins at 20\% acetone (Figure $6 \mathrm{~b}$, and data not shown). Similarly, P. sanguineus produced only one xylanase activity band under the conditions analyzed. Both xylanases bands were in the range of approximately 80 to $90 \mathrm{kDa}$.

\section{DISCUSSION}

The cost of the cellulolytic enzymes is one of the factors determining the economics of a biocatalytic process and it can be reduced finding optimum conditions for their production (Lynd et al. 2002). According to this, it is important to determine the hydrolytic capabilities of wooddegrading organisms to achieve better digestion of cellulosic materials for industrial purposes. In the present work, Bjerkandera adusta and Pycnoporus sanguineus, growing on a natural cellulosic substrate (wheat straw), produced a number of cellulolytic activities with different characteristics. Previous reports exist on the pretreatment of cellulosic substrates with white-rot fungi, achieving highquality levels of saccharification of the holocellulose (Taniguchi et al. 2005; Lee et al. 2007). At identical optimal culture conditions $\left(28^{\circ} \mathrm{C}\right.$ and $\left.\mathrm{pH} 5\right)$, maximal activities achieved by $B$. adusta were reached earlier (6 days of incubation vs. 8 in $P$. sanguineus), and at higher levels. Still, the requirements of culture conditions for both strains were the same. This was surprising given that $P$. sanguineus was isolated from a tropical location and grows better at high temperatures, indicating that the optimal growing temperature does not necessarily correlate with the optimal condition for producing cellulases. Nonetheless, one advantage of $P$. sanguineus (possibly due its increased thermotolerance) is the broad range of temperatures at which its enzymes achieve elevated activities (from 50 to $80^{\circ} \mathrm{C}$ ), whereas $B$. adusta activity showed a peak at $50^{\circ} \mathrm{C}$ (Figure 3). An additional difference between fungi was the tolerance of $P$. sanguineus enzymes to incubation at temperatures up to $60^{\circ} \mathrm{C}$ (Figure 4). This coincides with the notion that enzymes from thermophilic fungus present higher optimal temperature which could be related to longer "shelf-lives" for industrial applications (Maheshwari et al. 2000). Besides, thermostable cellulolytic enzymes also have great potential to be used in industrial processes such as food processing, textiles and bioconversion (Bhat and Bhat, 1997; Murray et al. 2004). One favorable attribute of $B$. adusta enzymes is their resistance to $1 \mathrm{hr}$ incubation from $\mathrm{pH} 2$ to 8 (Figure 4b). This is an important property that could allow degradation of previously acid- or alkalitreated material without the need to neutralize it. Since biological processes are more environmentally friendly compared to chemical pretreatments, these features make of these two species good candidates for biological pretreatment of wheat straw, using their enzymes either individually or in combination.

This is the first report of the characterization of the cellulolytic properties of any of the species herein presented. However, a recent report (Rodrigues et al. 2008),

focused on animal feeding, describes the use of fungal extracts to improve wheat straw digestibility, in which a strain of B. adusta was included. In it, volumetric CMCase and Avicelase activities where determined from liquid cultures, with values of approximately 0.14 and $0.1 \mathrm{IU} / \mathrm{ml}$, respectively, which correspond to 8.9- and 3.3-fold less than those found in this work $(1.25$ and $0.33 \mathrm{IU} / \mathrm{ml}$, respectively). The differences could be due to the method used to grow the fungus (see below). Nevertheless, in accordance with their findings, CMCase activity was also higher than the activity towards crystalline cellulose. Due to the variety of cellulosic media used to cultivate fungi, and to the different reported expression of cellulase activities, it is difficult to compare the efficacy of the enzymes analyzed in this work with others already described. In a report from (Nozaki et al. 2007), the enzymatic activities of the white rot basidiomycete Trametes hirsuta were measured using wheat bran (among other substrates) in solid media. They found that $T$. hirsuta enzymes were ten times more active in solid media than in liquid ones. Similarly, we observed higher activities (3-fold higher for B. adusta and 1.8-fold higher for $P$. sanguineus) in agar than in liquid cultures (data not shown). However, the activities achieved by the white rot fungi strains tested herein were 12- (B. adusta) and 7- ( $P$. sanguineus) fold higher than the values for $T$. hirsuta cultured under related conditions (Nozaki et al. 2007). The elevated activities presented in this work may be the result of the synergism of different types of enzymes produced by the evaluated fungi. Endo- and exo-glucanases, as well as -glucosidases and xylanases were expressed in the supernatants of both fungi, as revealed by the different substrates used in the reaction mixtures. It is important to note the existence of enzymes with elevated action on microcrystalline cellulose, in particular from $B$. adusta $(0.6 \mathrm{IU} / \mathrm{mg}$ vs. $0.26 \mathrm{IU} / \mathrm{mg}$ of $P$. sanguineus). It is also worth noting the high activity of $B$. adusta xylanases compared to $P$. sanguineus, particularly for applications such as in the paper and animal feeding industries (Polizeli et al. 2005; Alborés et al. 2006). Finally, the proteins responsible for the hydrolysis of CMC and two

a

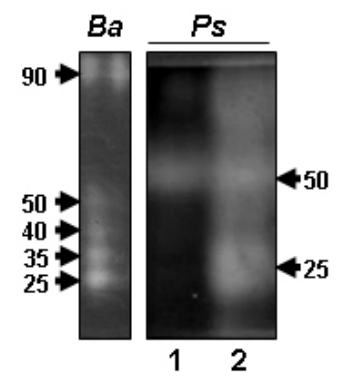

Figure 6. Zymograms of acetone-precipitated CMCases (a) and xylanases (b), from culture supernatants. $\mathrm{Ba}, \mathrm{B}$. adusta. Ps, P. sanguineus. Lane 1, 20\%-acetone faction; lane 2, 80\%acetone fraction. For details see Materials and Methods. Arrows indicate approximate MWs. 
types of xylan were detected by zymography. The CMCase activity bands identified in both strains showed molecular weights comparable to those reported for endo-glucanases from Trichoderma reesei and Phanerochaete chrysosporium, ranging from approximately 25 to $50 \mathrm{kDa}$. Endoglucanases play a key role in increasing the yield of fruit juices, beer filtration, and oil extraction, improving the nutritive quality of bakery products and animal feed, and enhancing the brightness, smoothness, and over all quality of cellulosic garments (Parry et al. 2002). Hence, there is a need for a wide range of enzymes with varying $\mathrm{pH}$ and temperature optima, stability, and substrate specifications. According to its size the high molecular weight band in supernatants from $B$. adusta could correspond to a $\beta$ glucosidase (Perez et al. 2002). In addition, under the conditions tested, both species expressed only one band of similar molecular weight (approximately 80 to $90 \mathrm{kDa}$ ) with xylanase activity. Xylanases have been clustered into different glycosyl hydrolases families (Collins et al. 2005). Given the MW encountered for xylanases from both fungi, it is tentatively suggested that they may belong to family 10, with a characteristic low isoelectric point (IP) (Wong et al. 1988). Purification of these proteins is currently being performed to confirm their features, and to establish their individual contribution to the total activity of the supernatants.

\section{REFERENCES}

ALBORÉS, S.; PIANZZOLA, M.J.; SOUBES, M. and CERDEIRAS, M.P. Biodegradation of agroindustrial wastes by Pleurotus spp for its use as ruminant feed. Electronic Journal of Biotechnology, June 2006, vol. 9, no. 3, p. 215-220.

BAYER, Edward A.; LAMED, Raphael and HIMMEL, Michael E. The potential of cellulases and cellulosomes for cellulosic waste management. Current Opinion in Biotechnology, June 2007, vol. 18, no. 3, p. 237-245.

BHAT, M.K. and BHAT, S. Cellulose degrading enzymes and their potential industrial applications. Biotechnology Advances, 1997, vol. 15, no. 3-4, p. 583-620.

COLLINS, Tony; GERDAY, Charles and FELLER, Georges. Xylanases, xylanase families and extremophilic xylanases. FEMS Microbiology Reviews, January 2005, vol. 29, no. 1, p. 3-23.

DANTÁN-GONZÁLEZ， E.; VITE-VALLEJO， O.; MARTÍNEZ-ANAYA, C.; MÉNDEZ-SÁNCHEZ, M.; GONZÁLEZ, M.C.; PALOMARES, L.A. and FOLCHMALLOL, J. Production of two novel laccase isoforms by a thermotolerant strain of Pycnoporus sanguineus isolated from an oil-polluted tropical habitat. International Microbiology, September 2008, vol. 11, no. 3, p. 163-169.

DOI, Roy H. Cellulases of mesophilic microorganisms: cellulosome and non-cellulosome producers. Annals of the
New York Academy of Sciences, March 2008, vol. 1125, no. 1, p. 267-279.

GERHARDT, Matthias; PELENC, Vincent and BÄUML, Markus. Application of hydrolytic enzymes in the agricultural biogas production: Results from practical applications in Germany. Biotechnology Journal, December 2007, vol. 2, no. 12, p. 1481-1484.

INGLIS, G.D.; POPP, A.P.; SELINGER, L.B.; KAWCHUK, L.M.; GAUDET, D.A. and MCALLISTER, T.A. Production of cellulases and xylanases by lowtemperature basidiomycetes. Canadian Journal of Microbiology, September 2000, vol. 46, no. 9, p. 860-865.

KIM, Seungdo and DALE, Bruce E. Global potential bioethanol production from wasted crops and crop residues. Biomass and Bioenergy, April 2004, vol. 26, no. 4, p. 361375.

LEE, Jae-Won; GWAK, Ki-Seob; PARK, Jun-Yeong; PARK, Mi-Jin; CHOI, Don-Ha; KWON, Mi and CHOI, InGyu. Biological pretreatment of softwood Pinus densiflora by three white rot fungi. The Journal of Microbiology, December 2007, vol. 45, no. 6, p. 485-491.

LEE, Yong-Eok; LOWE, Sue E. and ZEIKUS, J. Gregory. Regulation and characterization of xylanolytic enzymes of Thermoanaerobacterium saccharolyticum B6A-RI. Applied and Environmental Microbiology, March 1993, vol. 59, no. 3, p. 763-771.

LOWRY, Oliver H.; ROSEBROUGH, Nira J.; FARR, A. Lewis and RANDALL, Rose J. Protein measurement with the Folin phenol reagent. Journal of Biological Chemistry, November 1951, vol. 193, no. 1, p. 265-275.

LYND, Lee R.; WEIMER, Paul J.; VAN ZYL, Willem H. and PRETORIUS, Isak S. Microbial cellulose utilization: fundamentals and biotechnology. Microbiology and Molecular Biology Reviews, September 2002, vol. 66, no. 3, p. 506-577.

MAHESHWARI, Ramesh; BHARADWAJ, Girish and BHAT, Mahalingeshwara K. Thermophilic fungi: their physiology and enzymes. Microbiology and Molecular Biology Reviews, September 2000, vol. 64, no. 3, p. 461488.

MARTÍNEZ, A.T.; SPERANZA, M.; RUIZ-DUEÑAS, F.J.; FERREIRA, P.; CAMARERO, S.; GUILLÉN, F.; MARTÍNEZ, M.J.; GUTIÉRREZ, A. and DEL RÍO, J.C. Biodegradation of lignocellulosics: microbial, chemical, and enzymatic aspects of the fungal attack of lignin. International Microbiology, September 2005, vol. 8, no. 3, p. 195-204.

MATEOS, P.F.; JIMENEZ-ZURDO, J.I.; CHEN, J.; SQUARTINI, A.S.; HAACK, S.K.; MARTINEZMOLINA, E.; HUBBELL, D.H. and DAZZO, F.B. Cell- 
associated pectinolytic and cellulolytic enzymes in Rhizobium leguminosarum biovar trifolii. Applied and Environmental Microbiology, June 1992, vol. 58, no. 6, p. 1816-1822.

MILLER, G.L. Use of dinitrosalicylic acid reagent for determination of reducing sugar. Analytical Chemistry, March 1959, vol. 31, no. 3, p. 426-428.

MURRAY, Patrick; ARO, Nina; COLLINS, Catherine; GRASSICK, Alice; PENTTILA, Merja; SALOHEIMO, Markku and TUOHY, Maria. Expression in Trichoderma reesei and characterisation of a thermostable family $3 \beta$ glucosidase from the moderately thermophilic fungus Talaromyces emersonii. Protein Expression and Purification, December 2004, vol. 38, no. 2, p. 248-257.

NAGLE, Nicholas J.; ELANDER, Richard T.; NEWMAN, Mildred M.; ROHRBACK, Brian T.; RUIZ, Raymond O. and TORGET, Robert W. Efficacy of a hot washing process for pretreated yellow poplar to enhance bioethanol production. Biotechnology Progress, July-August 2002, vol. 18, no. 4, p. 734-738.

NGUYEN, Quang A.; TUCKER, Melvin P.; KELLER, Fred A. and EDDY, Fannie P. Two-stage dilute-acid pretreatment of softwoods. Applied Biochemistry and Biotechnology, March 2000, vol. 84-86, no. 1-9, p. 561576.

NIDETZKY, B.; STEINER, W.; HAYN, M. and CLAEYSSENS, M. Cellulose hydrolysis by the cellulases from Trichoderma reesei: a new model for synergistic interaction. Biochemical Journal, March 1994, vol. 298, no. 3, p. 705-710.

NOZAKI, Kouichi; SEKI, Takahiro; MATSUI, Keiko; MIZUNO, Masahiro; KANDA, Takahisa and AMANO, Yoshihiko. Structure and characteristics of an endo- $\beta-1,4-$ glucanase, isolated from Trametes hirsuta, with high degradation to crystalline cellulose. Bioscience Biotechnology and Biochemistry, October 2007, vol. 71, no. 10, p. 2375-2385.

PARRY, N.J.; BEEVER, D.E.; OWEN, E.; NERINCKX, W.; CLAEYSSENS, M.; VAN BEEUMEN, J. and BHAT, M.K. Biochemical characterization and mode of action of a thermostable endoglucanase purified from Thermoascus aurantiacus. Archives of Biochemistry and Biophysics, August 2002, vol. 404, no. 2, p. 243-253.

PEREZ, J.; MUÑOZ-DORADO, J.; DE LA RUBIA, T. and MARTINEZ, J. Biodegradation and biological treatments of cellulose, hemicellulose and lignin: an overview. International Microbiology, June 2002, vol. 5, no. 2, p. 5363.

POLIZELI, M.L.T.M.; RIZZATTI, A.C.S.; MONTI, R.; TERENZI, H.F.; JORGE, J.A. and AMORIM, D.S. Xylanases from fungi: properties and industrial applications. Applied Microbiology and Biotechnology, June 2005, vol. 67, no. 5, p. 577-591.

RODRIGUES, M.A.M.; PINTO, P.; BEZERRA, R.M.F.; DIAS, A.A.; GUEDES, C.V.M.; CARDOSO, V.M.G.; CONEC, J.W.; FERREIRA, L.M.M.; COLACO, J. and SEQUEIRA, C.A. Effect of enzyme extracts isolated from white-rot fungi on chemical composition and in vitro digestibility of wheat straw. Animal Feed Science and Technology, April 2008, vol. 141, no. 3-4, p. 326-338.

SÖDERSTRÖM, Johanna; PILCHER, Linda; GALBE, Mats and ZACCHI, Guido. Two-step steam pretreatment of softwood with $\mathrm{SO}_{2}$ impregnation for ethanol production. Applied Biochemistry and Biotechnology, March 2002, vol. 98-100, no. 1-9, p. 5-21.

TANIGUCHI, Masayuki; SUZUKI, Hiroyuki; WATANABE, Deisuke; SAKAI, Kenji; HOSHINO, Kazuhiro and TANAKA, Takaaki. Evaluation of pretreatment with Pleurotus ostreatus for enzymatic hydrolysis of rice straw. Journal of Bioscience and Bioengineering, December 2005, vol. 100, no. 6, p. 637643.

VILLENA, Gretty K. and GUTIÉRREZ-CORREA, Marcel. Production of lignocellulolytic enzymes by Aspergillus niger biofilms at variable water activities. Electronic Journal of Biotechnology, January 2007, vol. 10, no. 1, p. 124-131.

WANG, Y.; VAZQUEZ-DUHALT, R. and PICKARD, M.A. Manganese-lignin peroxidase hybrid from Bjerkandera adusta oxidizes polycyclic aromatic hydrocarbons more actively in the absence of manganese. Canadian Journal of Microbiology, November 2003, vol. 49, no. 11, p. 675-682.

WONG, Ken K.Y.; TAN, Larry U.L. and SADDLER, John $\mathrm{N}$. Multiplicity of $\beta-1,4$-xylanase in microorganisms: functions and applications. Microbiology and Molecular Biology Reviews, September 1988, vol. 52, no. 3, p. 305317.

WYMAN, C.E.; DALE, B.E.; ELANDER, R.T.; HOLTZAPPLE, M.; LADISCH, M.R. and LEE, Y.Y. Coordinated development of leading biomass pretreatment technologies. Bioresource Technology, December 2005, vol. 96, no. 18, p. 1959-1966. 